\title{
Investigation of heat transfer between neighbouring apartments
}

\author{
Anti Hamburg, Martin Thalfeldt, Teet-Andrus Kõiv, Alo Mikola \\ Department of Environmental Engineering, Tallinn University of Technology, Ehitajate tee 5, Tallinn 19086, Estonia
}

\begin{abstract}
Little attention has been paid to the heat conductivity of internal walls and floors as it does not significantly affect heat losses of a building. However, it is important to study heat transfer between apartments. In the framework of the current study, on site heat conductivity measurements were transmitted to support the results received by energy simulations.

Increasing energy efficiency of buildings has become one of the severe problems that has to be solved in the near future. The goal of reducing carbon dioxide $\left(\mathrm{CO}_{2}\right)$ emission by $20 \%$ by the year 2020 has been set to all EU members states. As residential sector is responsible for a large part of energy consumption, it is clear that refurbishing dwellings is an effective means of reducing $\mathrm{CO}_{2}$ emissions. In case of old apartment buildings, space heating is the single most common contributor to greenhouse gas emissions [1].

Space heating consumption of apartment buildings can mainly be reduced by insulating the envelope and installing windows with low heat conductivity. As heat losses of buildings are reduced, thermostatic radiator valves (TRVs) must be installed. Studies show that TRVs can contribute greatly to reducing heating consumption, however it is also noted that they must be used correctly [2, 3]. The use of thermostats has been studied by Karjalainen and it was concluded that due to different reasons, large part of people do not know how to use TRVs $[4,5]$.

One means of drawing more dwelling residents' attention to TRVs is implementing energy allocation systems that record the energy consumption and divide it between flats [6]. The system motivates inhabitants to learn how to use TRVs, as the residents have some control over their energy bills. However, besides benefits, the system can cause problems as well.

In our case study we look what is going to happen when we change one room set point temperature and how much heatflow coming or going through wall between neighbouring apartment. There we can see that when unheated room have set point temperature $16^{\circ} \mathrm{C}$ and don't have any internal heat gains then it doesn't need any heating energy because heatflow from neighboring apartments covers it.
\end{abstract}

Keywords: Heatflow between apartments; allocation system; energy simulation.

\section{Introduction}

The purpose of the current study is to analyse potential heat transfer between neighbouring apartments and assessing its effect on apartments' energy bills if heat allocation systems are used. The analysis has been done by simulating the energy consumption and indoor climate of a simple 5-storey apartment building in the cold climate of Estonia. The average outside air temperature during heating period is around $0{ }^{\circ} \mathrm{C}$. In case of indoor temperatures of $+21^{\circ} \mathrm{C}$, the room temperature difference of $1{ }^{\circ} \mathrm{C}$ roughly affects heating energy consumption by $5 \%$. However, heat also transfers from one apartment to another in case of diverse indoor temperatures within the building. Therefore it is assumed that temperature change in one single apartment has much bigger effect on the heating bills of the apartment and the ones surrounding it.

By using heat allocation systems, the inhabitants are motivated to reduce indoor air temperatures of their apartments. As the heat conductivity of interior walls and ceilings is significantly higher than of exterior ones, heat flows between apartments occur and they are difficult to estimate [6]. As a result the heat losses of an apartment can be eventually compensated by the heat emitted by radiators of another one, thus causing inequality. The results of experiments conducted by Parsons suggested that by adjusting clothing, indoor thermal comfort can be achieved within temperature range of $+18 \ldots+27^{\circ} \mathrm{C}[7]$. The lower limit $+18^{\circ} \mathrm{C}$ is significantly lower than normally accepted indoor temperatures of $+21{ }^{\circ} \mathrm{C}$. Furthermore, in literature survey by Frontczak and Wargocki about different factors' influence on human comfort in indoor environments, it was pointed out that in naturally ventilated buildings, acceptable temperature range is even wider than in buildings with mechanical ventilation [8].

Corresponding author: Teet-Andrus Kõiv. E-mail: teet.koiv@ttu.ee

http://dx.doi.org/10.3846/enviro.2014.261

(C) 2014 The Authors. Published by VGTU Press. This is an open-access article distributed under the terms of the Creative Commons Attribution License, which permits unrestricted use, distribution, and reproduction in any medium, provided the original author and source are credited. 
The effect of temperature differences between apartments on energy bills is often underestimated. The aim of this study is to find out how much does change of indoor temperature in an apartment affects heating consumption fluctuations in adjacent apartments and also how much does the temperature drops in an apartment if the TRVs are shut off. Studies have shown that thermal mass of structures influences the load characteristics and energy demand of buildings [9]. Temperature fluctuations during day and night period make heat flow calculations complicated [10]. As the structures of existing refurbished apartment buildings are heavy, the calculations are complex and therefore energy simulations were used in the analysis.

\section{Methods and Situation}

Energy simulation software IDA ICE 4.5 was used to calculate heat transmission between apartments and indoor air temperatures. This software allows the modelling of a multi-zone building, HVAC-systems, internal and solar loads, outdoor climate, etc. and provides simultaneous dynamic simulation of heat transfer and air flows. It is a suitable tool for the simulation of thermal comfort, indoor air quality, and energy consumption in complex buildings. A modular simulation application, IDA ICE, has been developed by the Division of Building Services Engineering, KTH, and the Swedish Institute of Applied Mathematics, ITM [11]. IDA ICE has been tested against measurements [12] and several independent inter-model comparisons have been made [13]. In the comparisons, the performance of radiant heating and cooling systems using five simulation programs (CLIM2000, DOE, ESP-r, IDA ICE and TRNSYS) were compared and IDA ICE showed a good agreement with the other programs. The tests and the comparisons showed a good justification for selecting IDA ICE as a reference tool in this study. Estonian test reference year was used in the simulations [14].

The created simulation model was built based on building type 121-E05 (prefabricated concrete block building type with 5 floors). It was assumed that external walls have an extra $100 \mathrm{~mm}$ thermal insulation layer and heat conductivity of $0.28 \mathrm{~W} /\left(\mathrm{m}^{2} \mathrm{~K}\right)$. On the roof, extra $150 \mathrm{~mm}$ thermal insulation was added. Air exchange with the infiltration was assumed to be $0.51 / \mathrm{h}$ in all zones. The glass thermal conductivity of windows was assumed to be $1.6 \mathrm{~W} /\left(\mathrm{m}^{2} \mathrm{~K} 0\right.$, and the thermal conductivity of window frames $2 \mathrm{~W} /\left(\mathrm{m}^{2} \mathrm{~K}\right)$ (Table 1). The thermal bridges of the building were taken into account in the values which are shown in (Table 2).

Table 1. External elements or constructions of the building

\begin{tabular}{lll}
\hline External surface & $\mathrm{U}$-value $\left(\mathrm{W} / \mathrm{m}^{2} \cdot \mathrm{K}\right)$ & Area $\left(\mathrm{m}^{2}\right)$ \\
\hline Wall & 0.29 & 1317 \\
External door & 2.6 & 15,6 \\
Roof & 0.17 & 271 \\
Floor between downstairs floor & 1.6 & 271 \\
Windows & 1.68 & 517 \\
\hline
\end{tabular}

Table 2. External elements of the building

\begin{tabular}{ll}
\hline Thermal bridge & Thermal bridge conductivity \\
& $\Psi \mathrm{j}(\mathrm{W} / \mathrm{m} * \mathrm{~K})$ \\
\hline External wall/internal slab & 0.2 \\
External wall/ internal wall & 0.1 \\
External wall/external wall & 0.3 \\
External windows perimeter & 0.1 \\
External door perimeter & 0.1 \\
Roof/external wall & 0.2 \\
External slab/external wall & 0.3 \\
Balcony floor/external wall & 0.5 \\
\hline
\end{tabular}

Basic analysis shows that "zone 1" was most affected by boundaries, such as the inner wall of the apartment with a high thermal conductivity value $4.2 \mathrm{~W} / \mathrm{m}^{2} * \mathrm{~K}$ (Table 3 ).

The goal of simulations was to investigate the heat transfer between neighbouring rooms located in different apartments. Investigated zone "zone 1" was located in a typical five-storey prefabricated concrete panel building which had four stairwells and 60 apartments. Building type was 121-E05. "Zone 1" - a room from a smaller apartment - was located on the third floor, in the mid-stairwell (Table 1), and during the study, impact of zone 1 on a neighbouring apartment (its top, bottom, and side) was evaluated, and the partitions of the heat flux were rated. 
Table 3. Zone 1 surfaces

\begin{tabular}{lll}
\hline Surface & $\mathrm{U}$-value $\left(\mathrm{W} / \mathrm{m}^{2} \cdot \mathrm{K}\right)$ & Area $\left(\mathrm{m}^{2}\right)$ \\
\hline Wall between same apartment & 4.2 & 13.6 \\
Door between same apartment & 2.6 & 1.6 \\
Ceiling between upper floor & 2.13 & 7.7 \\
Floor between downstairs floor & 2.13 & 7.7 \\
External wall & 0.27 & 4 \\
Windows & 1.68 & 7 \\
Wall between zone 2 & 4.2 & 6.4 \\
\hline
\end{tabular}

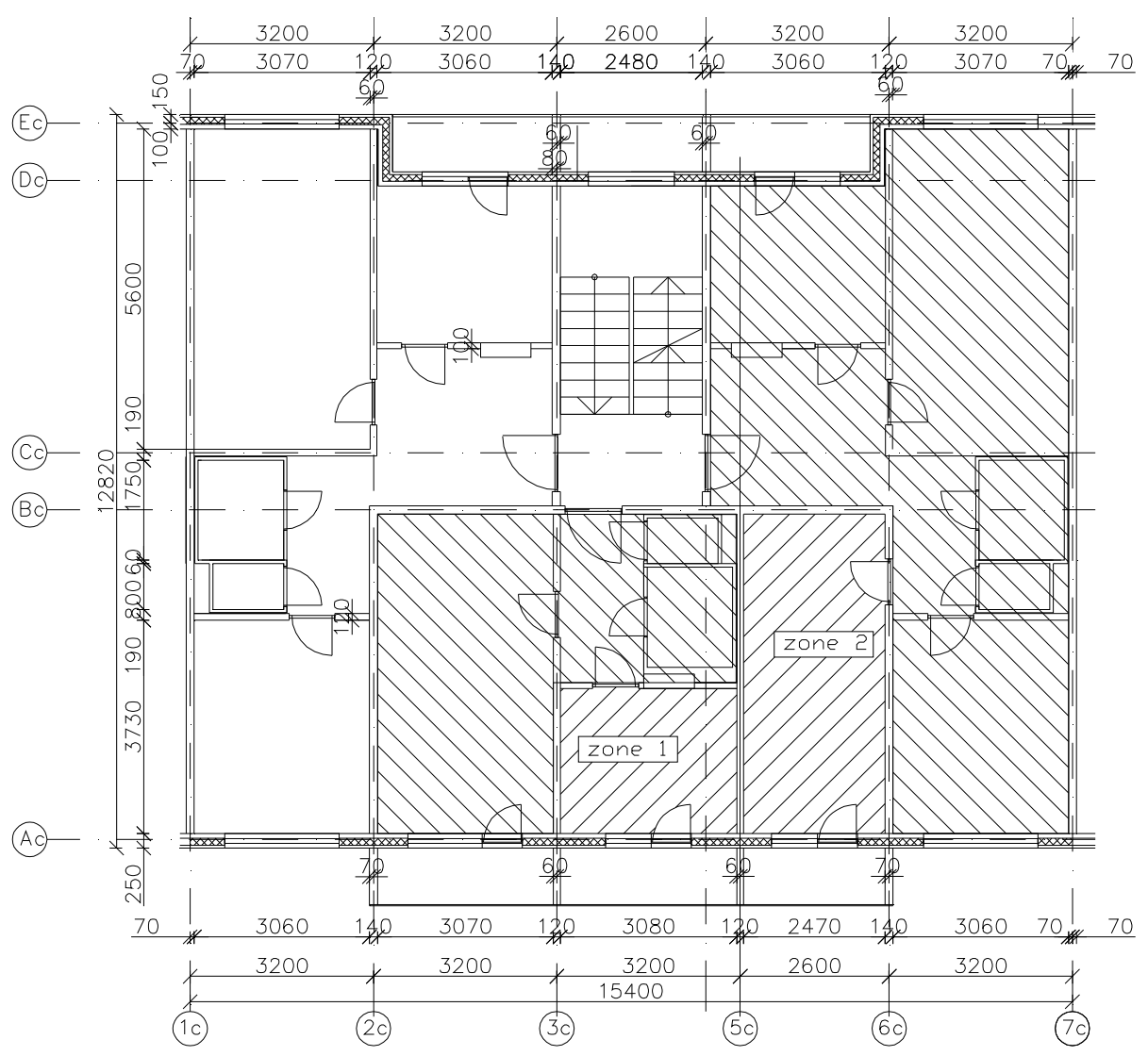

Fig. 1. Section from apartment building

The study focused on the impact of "zone 1" to the room in the neighbouring apartment - "zone 2".

Heat transfer analysis was carried out with the following options:

- Building of a standard usage: all apartments have the same indoor temperature and similar internal heatgains. This was used as a base model for the rest of simulation models.

- All apartments have an internal air temperature of $21^{\circ} \mathrm{C}$

- Internal heat gains $\left(2.4 \mathrm{~W} / \mathrm{m}^{2}\right.$ equipment, 8.0 lighting)

- Apartment doors are opened

- Compared to the base model, it was assumed that the internal temperature of test zone ,zone 1 “is $23{ }^{\circ} \mathrm{C}$

- Compared to the base model it was assumed that the internal temperature of test zone ,zone 1 “ is $19^{\circ} \mathrm{C}$

- Compared to the base model it was assumed that the internal temperature of test zone „zone 1 “ is $16^{\circ} \mathrm{C}$, there are no internal heat gains, and the door of "zone 1 " is closed.

\section{Simulation results}

The existing situation was that the building's heating energy consumption between 1st September and 30th April was $260476 \mathrm{kWh}$. In the apartment of "zone 1", the overall heating energy consumption was $1660.6 \mathrm{kWh}$ and the heating energy consumption of "zone 1" was $881.3 \mathrm{kWh}$. The heating energy consumption of a neighbouring apartment was $3154.5 \mathrm{kWh}$ while "zone 2" formed $494.7 \mathrm{kWh}$ of the energy consumption. The apartment of "zone 1" constituted $0.34 \%$. 
of the entire building's heating energy consumption. The following analyses was based on the heating energy analyses between apartments of "zone 1" and "zone 2". As the room depth of "zone 1" was smaller, than the depth of "zone 2", the free heat gain from the sun had a considerable effect to the heat flow of the walls. Bigger heat gain from sun in „zone 1“ caused the heat flow to "zone 2" which resulted in $22.4 \mathrm{kWh}$ (Table 4) mainly between September and April, forming totally $2.5 \%$ of the "zone 1 " heating consumption. The average heat flow to "zone 2 " was $3.8 \mathrm{~W}$, that is $0.6 \mathrm{~W} / \mathrm{m}^{2}$ per wall area.

Table 4. Zone Surface heat flowes

\begin{tabular}{|c|c|c|c|c|c|c|c|c|c|}
\hline & \multicolumn{9}{|c|}{ Variables } \\
\hline & $\begin{array}{l}\text { Heatflow } \\
\text { through } \\
\text { ceiling, } \\
\text { W }\end{array}$ & $\begin{array}{l}\text { Heatflow } \\
\text { through door, } \\
\text { W }\end{array}$ & $\begin{array}{l}\text { Heatflow } \\
\text { through floor, } \\
\mathrm{W}\end{array}$ & $\begin{array}{l}\text { Heatflow } \\
\text { through inside } \\
\text { wall } 1 \text {, } \\
\text { W }\end{array}$ & $\begin{array}{l}\text { Heatflow to } \\
\text { zone } 2 \text {, } \\
\text { W }\end{array}$ & $\begin{array}{l}\text { Heatflow } \\
\text { through } \\
\text { external wall, } \\
\text { W }\end{array}$ & $\begin{array}{l}\text { Heatflow } \\
\text { through inside } \\
\text { wall on west, } \\
\text { W }\end{array}$ & $\begin{array}{l}\text { Heatflow } \\
\text { through } \\
\text { window 1, } \\
\text { W }\end{array}$ & $\begin{array}{l}\text { Heatflow } \\
\text { through } \\
\text { window 2, } \\
\text { W }\end{array}$ \\
\hline September & 4.5 & 0.1 & -4.1 & -2.8 & -5.1 & -9.4 & -0.9 & -28.4 & -31.6 \\
\hline October & 4.2 & -0.1 & -0.6 & -4.2 & -3.9 & -15.5 & -1.3 & -40.7 & -46.0 \\
\hline November & 3.2 & -0.5 & -0.4 & -4.1 & -2.5 & -23.2 & -1.8 & -58.5 & -67.7 \\
\hline December & 3.0 & -0.6 & -0.8 & -3.4 & -2.2 & -26.5 & -1.9 & -65.9 & -76.6 \\
\hline January & 3.2 & -0.6 & -0.7 & -3.1 & -2.3 & -26.9 & -2.2 & -67.4 & -78.5 \\
\hline February & 5.7 & -0.6 & 0.3 & -6.2 & -3.4 & -28.5 & -3.0 & -70.6 & -80.8 \\
\hline March & 9.2 & -0.5 & -1.9 & -6.1 & -6.5 & -20.5 & -3.1 & -53.1 & -59.8 \\
\hline April & 7.8 & -0.3 & -2.3 & -3.7 & -4.9 & -16.6 & -3.3 & -41.9 & -48.1 \\
\hline mean & 5.1 & -0.4 & -1.3 & -4.2 & -3.8 & -20.9 & -2.2 & -53.3 & -61.1 \\
\hline mean*5832.0 h & 29710.7 & -2361.8 & -7653.5 & -24389.3 & -22384.6 & -121834.8 & -12746.1 & -310911.1 & -356356.7 \\
\hline $\min$ & 3.0 & -0.6 & -4.1 & -6.2 & -6.5 & -28.5 & -3.3 & -70.6 & -80.8 \\
\hline $\max$ & 9.2 & 0.1 & 0.3 & -2.8 & -2.2 & -9.4 & -0.9 & -28.4 & -31.6 \\
\hline
\end{tabular}

If we raise "zone 1" temperature to $23^{\circ} \mathrm{C}$, it causes a significant change in heat flow through the inner walls to "zone 2 " (Table 5), which is $303.0 \mathrm{kWh}$ during the heating season. Compared to previous simulation, the heat flow has increased by $280.6 \mathrm{kWh}$. Also we can see the increased heat flow through the rest of the internal border. Most of the heat is moving to the "zone 1" apartment through the interior walls and door. If in the previous simulation, the rest of this apartment's heating energy need was $1212.5 \mathrm{kWh}$, then in this situation is it only $6.0 \mathrm{kWh}$. "Zone 1 " heating energy need increased more than 3 times: from $881.3 \mathrm{kWh}$ to $2928.3 \mathrm{kWh}$. Therefore, the energy consumption of the whole apartment increased up to $2934.3 \mathrm{kWh}$, which is 1.75 times more than in the previous simulation. This situation helps us better understand why it is needed to use an allocation system as an instrument for saving heating energy.

Table 5. Surface heatflowes ("zone $1 " 23{ }^{\circ} \mathrm{C}$, with internal gains)

\begin{tabular}{|c|c|c|c|c|c|c|c|c|c|}
\hline & \multicolumn{9}{|c|}{ Variables } \\
\hline & $\begin{array}{l}\text { Heatflow } \\
\text { through } \\
\text { ceiling, } \\
\text { W }\end{array}$ & $\begin{array}{l}\text { Heatflow } \\
\text { through door, } \\
\text { W }\end{array}$ & $\begin{array}{l}\text { Heatflow } \\
\text { through floor, } \\
\text { W }\end{array}$ & $\begin{array}{l}\text { Heatflow } \\
\text { through inside } \\
\text { wall } 1 \text {, } \\
\text { W }\end{array}$ & $\begin{array}{l}\text { Heatflow to } \\
\text { zone } 2 \text {, } \\
\text { W }\end{array}$ & $\begin{array}{l}\text { Heatflow } \\
\text { through } \\
\text { external wall, } \\
\text { W }\end{array}$ & $\begin{array}{l}\text { Heatflow } \\
\text { through inside } \\
\text { wall on west, } \\
\text { W }\end{array}$ & $\begin{array}{l}\text { Heatflow } \\
\text { through } \\
\text { window 1, } \\
\text { W }\end{array}$ & $\begin{array}{l}\text { Heatflow } \\
\text { through } \\
\text { window 2, } \\
\text { W }\end{array}$ \\
\hline September & -6.0 & -3.6 & -12.8 & -12.2 & -21.3 & -10.6 & -11.1 & -30.4 & -33.9 \\
\hline October & -23.8 & -11.6 & -25.0 & -33.1 & -51.5 & -17.7 & -32.2 & -46.1 & -52.3 \\
\hline November & -29.4 & -16.5 & -29.0 & -44.4 & -60.5 & -25.7 & -44.9 & -64.8 & -75.0 \\
\hline December & -29.5 & -17.9 & -29.7 & -47.3 & -60.4 & -29.1 & -48.6 & -72.2 & -84.0 \\
\hline January & -29.3 & -18.1 & -29.6 & -47.2 & -60.7 & -29.3 & -49.2 & -73.8 & -85.9 \\
\hline February & -26.7 & -17.1 & -28.1 & -47.9 & -60.3 & -31.0 & -47.8 & -76.8 & -88.1 \\
\hline March & -17.3 & -12.0 & -24.9 & -35.0 & -51.3 & -22.5 & -33.9 & -58.2 & -65.7 \\
\hline April & -18.8 & -11.0 & -25.5 & -30.6 & -49.6 & -18.4 & -32.1 & -47.0 & -54.1 \\
\hline mean & -22.6 & -13.5 & -25.6 & -37.2 & -52.0 & -23.0 & -37.5 & -58.6 & -67.4 \\
\hline mean*5832.0 h & -131947.1 & -78579.4 & -149142.9 & -217115.1 & -303042.9 & -134320.3 & -218635.7 & -342041.2 & -392938.3 \\
\hline $\min$ & -29.5 & -18.1 & -29.7 & -47.9 & -60.7 & -31.0 & -49.2 & -76.8 & -88.1 \\
\hline $\max$ & -6.0 & -3.6 & -12.8 & -12.2 & -21.3 & -10.6 & -11.1 & -30.4 & -33.9 \\
\hline
\end{tabular}


The third option meant reducing the temperature of the analysed "zone 1 " from $21^{\circ} \mathrm{C}$ to $19{ }^{\circ} \mathrm{C}$ in order to see the impact on neighbouring zones. Simulation results show that in "zone 1" there was no need for extra heating anymore and with the support of the neighbouring zones the temperature did not fall below $20.1^{\circ} \mathrm{C}$ in "zone 1 ". Most of the heat energy was coming from the same apartment though the door and the inner wall (Table 6).

Table 6. Surface heatflowes ("zone 1 " $19^{\circ} \mathrm{C}$, with internal gains)

\begin{tabular}{|c|c|c|c|c|c|c|c|c|c|}
\hline & \multicolumn{9}{|c|}{ Variables } \\
\hline & $\begin{array}{l}\text { Heatflow } \\
\text { through } \\
\text { ceiling, } \\
\text { W }\end{array}$ & $\begin{array}{l}\text { Heatflow } \\
\text { through door, } \\
\text { W }\end{array}$ & $\begin{array}{l}\text { Heatflow } \\
\text { through floor, } \\
\text { W }\end{array}$ & $\begin{array}{l}\text { Heatflow } \\
\text { through inside } \\
\text { wall } 1 \text {, } \\
\text { W }\end{array}$ & $\begin{array}{l}\text { Heatflow to } \\
\text { zone } 2 \text {, } \\
\text { W }\end{array}$ & $\begin{array}{l}\text { Heatflow } \\
\text { through } \\
\text { external wall, } \\
\text { W }\end{array}$ & $\begin{array}{l}\text { Heatflow } \\
\text { through inside } \\
\text { wall on west, } \\
\text { W }\end{array}$ & $\begin{array}{l}\text { Heatflow } \\
\text { through } \\
\text { window 1, } \\
\text { W }\end{array}$ & $\begin{array}{l}\text { Heatflow } \\
\text { through } \\
\text { window 2, } \\
\text { W }\end{array}$ \\
\hline September & 5.1 & 0.2 & -3.8 & -2.2 & -4.4 & -9.3 & -0.4 & -28.4 & -31.5 \\
\hline October & 9.9 & 3.5 & 4.7 & 5.0 & 6.6 & -14.8 & 8.7 & -39.6 & -44.6 \\
\hline November & 15.8 & 7.8 & 11.7 & 17.3 & 21.0 & -22.0 & 20.9 & -56.1 & -64.8 \\
\hline December & 18.0 & 9.6 & 13.9 & 22.5 & 26.4 & -25.3 & 25.9 & -62.9 & -73.1 \\
\hline January & 18.6 & 9.8 & 14.3 & 23.4 & 26.9 & -25.5 & 26.2 & -64.4 & -74.9 \\
\hline February & 19.6 & 8.9 & 13.8 & 17.6 & 23.2 & -27.7 & 22.6 & -67.8 & -77.5 \\
\hline March & 16.4 & 3.8 & 4.7 & 5.1 & 6.1 & -19.8 & 8.7 & -51.8 & -58.2 \\
\hline April & 12.1 & 2.7 & 2.2 & 3.9 & 3.8 & -16.6 & 4.7 & -40.9 & -46.9 \\
\hline mean*5832.0 h & 84245.9 & 33739.1 & 44958.4 & 67437.6 & 79901.7 & -117400.0 & 85557.3 & -300167.0 & -343730.1 \\
\hline$\overline{\min }$ & 5.1 & 0.2 & -3.8 & -2.2 & -4.4 & -27.7 & -0.4 & -67.8 & -77.5 \\
\hline$\overline{\max }$ & 19.6 & 9.8 & 14.3 & 23.4 & 26.9 & -9.3 & 26.2 & -28.4 & -31.5 \\
\hline
\end{tabular}

The heating energy need for the same apartment increased by $1439.7 \mathrm{kWh}$. When compared to basic situation, the heating energy consumption of this apartment was reduced by $220.1 \mathrm{kWh}$. $79.9 \mathrm{kWh}$ derived from "zone 2". From this situation we can see that even when the temperature in "zone 1 " is reduced to $16^{\circ} \mathrm{C}$ on thermostat, it is impossible to achieve lower temperature than $20.1 \mathrm{C}$ Also we can see that the effect of reducing temperature does not cause a significant change in the need for heating energy at the neighbouring apartments and at the flat of "zone 1".

Effect can be seen in a situation when the "zone 1" door of the same apartment is closed, there are no internal heat gains and the thermostat set point is $16^{\circ} \mathrm{C}$. This temperature has been chosen to show effect in a situation when thermostats with limiter are used. In this case we can see that the heat flow through the wall between "zone 2 " increased to $201.1 \mathrm{kWh}$ (Table 7). During heating season, the average heat flow through the neighbouring apartment is $34.5 \mathrm{~W}$ and in December and January it is approximately $58 \mathrm{~W}$ that is $9 \mathrm{~W} / \mathrm{m}^{2}$ per wall area. The entire heating energy consumption of the neighbouring apartment increased from $3154.5 \mathrm{kWh}$ to $3363.2 \mathrm{kWh}$ that is by $6.2 \%$. In the apartment of "zone 1", the consumption was reduced to $1203.7 \mathrm{kWh}$, that is $27.5 \%$. "Zone 1 " heating energy consumption was only $0.4 \mathrm{kWh}$, which is approximately 0 .

Table 7. Surface heat flows (“zone 1 " $16^{\circ} \mathrm{C}$, no internal gains)

\begin{tabular}{|c|c|c|c|c|c|c|c|c|c|}
\hline & \multicolumn{9}{|c|}{ Variables } \\
\hline & $\begin{array}{l}\text { Heatflow } \\
\text { through } \\
\text { ceiling, } \\
\text { W }\end{array}$ & $\begin{array}{l}\text { Heatflow } \\
\text { through door, } \\
\text { W }\end{array}$ & $\begin{array}{l}\text { Heatflow } \\
\text { through floor, } \\
\text { W }\end{array}$ & $\begin{array}{l}\text { Heatflow } \\
\text { through inside } \\
\text { wall } 1, \mathrm{~W}\end{array}$ & $\begin{array}{l}\text { Heatflow to } \\
\text { zone } 2 \text {, } \\
\text { W }\end{array}$ & $\begin{array}{l}\text { Heatflow } \\
\text { through } \\
\text { external wall, } \\
\text { W }\end{array}$ & $\begin{array}{l}\text { Heatflow } \\
\text { through inside } \\
\text { wall on west, } \\
\text { W }\end{array}$ & $\begin{array}{l}\text { Heatflow } \\
\text { through } \\
\text { window 1, } \\
\text { W }\end{array}$ & $\begin{array}{l}\text { Heatflow } \\
\text { through } \\
\text { window 2, } \\
\text { W }\end{array}$ \\
\hline September & 4.3 & 0.3 & 0.2 & 2.5 & 1.6 & -8.8 & 4.6 & -24.7 & -27.4 \\
\hline October & 13.8 & 2.6 & 14.3 & 14.7 & 20.9 & -13.5 & 19.4 & -33.9 & -38.1 \\
\hline November & 25.4 & 6.4 & 29.6 & 34.5 & 47.5 & -19.9 & 39.8 & -47.6 & -55.0 \\
\hline December & 30.1 & 7.9 & 35.4 & 42.9 & 58.1 & -23.2 & 48.0 & -53.3 & -61.9 \\
\hline January & 30.6 & 8.1 & 36.1 & 44.4 & 59.2 & -23.0 & 48.8 & -54.6 & -63.5 \\
\hline February & 27.9 & 6.8 & 32.9 & 36.9 & 51.1 & -26.0 & 43.4 & -58.2 & -66.5 \\
\hline March & 17.1 & 2.7 & 14.3 & 15.8 & 20.5 & -18.9 & 20.6 & -45.2 & -50.6 \\
\hline April & 13.4 & 2.6 & 10.6 & 13.8 & 16.8 & -15.7 & 15.4 & -35.4 & -40.5 \\
\hline mean*5832.0 h & 118607.8 & 27235.0 & 126406.5 & 149990.0 & 201052.4 & -108446.0 & 175013.4 & -257196.5 & -293965.9 \\
\hline $\min$ & 4.3 & 0.3 & 0.2 & 2.5 & 1.6 & -26.0 & 4.6 & -58.2 & -66.5 \\
\hline $\max$ & 30.6 & 8.1 & 36.1 & 44.4 & 59.2 & -8.8 & 48.8 & -24.7 & -27.4 \\
\hline
\end{tabular}




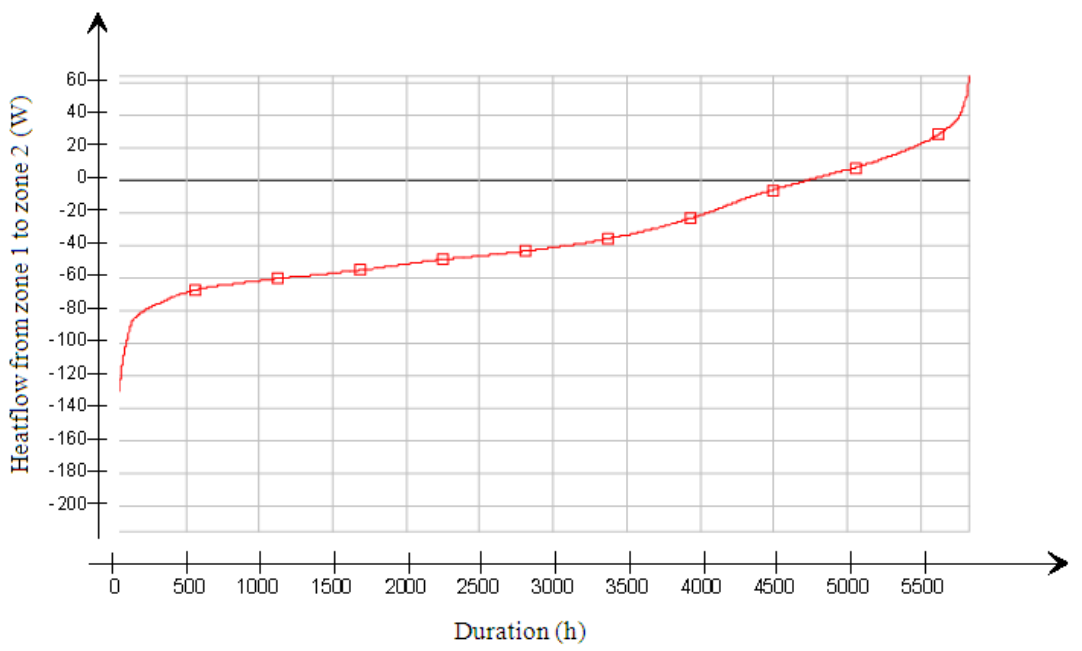

Fig. 2. Heatflow from zone 2 to zone 1

Figure 2 shows how much heat is going through "zone 2" internal wall to "zone 1" when zone 1 set point temperature is $16^{\circ} \mathrm{C}$ and it has no internal gains. The reason why some heat came from the opposite way is because of "zone 1 " heat gain through windows. "Zone 1" has larger windows per room area than "zone 2".

Based on this it can be concluded that in case of an opposite situation there is no heat flow from "zone 2" to "zone 1".

\section{Conclusion}

When comparing different situations of "zone 1", we can see a major effect from heat transfer between neighbouring apartments when "zone 1 " temperature set point is $16^{\circ} \mathrm{C}$ and there are no internal gains. In this situation we can see that the heat flow through the wall between "zone 2 " increased to $201.1 \mathrm{kWh}$ which is $23 \%$ from "zone 1 " energy need on set point temperature $21^{\circ} \mathrm{C}(881.3 \mathrm{kWh})$. Also we can see same situation from other neighbouring apartments (upper and down floor) where increase heating energy need totally $245 \mathrm{kWh}$ (Table 7).

This situation can occur mainly in the flats inhabited by elderly people whose children have moved away and where some rooms are not being used or when inhabitants are away for longer period. When we look at the age of those buildings, which is approximately 30 years or even more, the situation is quite normal. The age of the buildings must also be considered in case of using individual allocation systems, otherwise it may happen that people living in these apartments partly cover the heating costs of their neighbours.

\section{References}

[1] Kyrö, R.; Heinonen, J. ;Säynäjoki, A. 2011. Junnila, S. Occupants have little influence on overall energy consumption in district heated apartment buildings, Energy and Buildings 43: 3484-3490. http://dx.doi.org/10.1016/j.enbuild.2011.09.012

[2] Xu, B. P.; Huang, A.; Fu, L.; Di, H. F. 2011. Simulation and analysis on control effectiveness of TRVs in district heating systems, Energy and Buildings43: 1169-1174. http://dx.doi.org/10.1016/j.enbuild.2010.08.030

[3] Xu, B. P.; Huang, A.; Fu, L.; Di, H. F. 2008. Dynamic simulation of space heating systems with radiators controlled by TRVs in buildings, Energy and Buildings 40: 1755-1764. http://dx.doi.org/10.1016/j.enbuild.2008.03.004

[4] Karjalainen, S. 2007. Gender differences in thermal comfort and use of thermostats in everyday thermal environments, Building and Environment 42: 1594-1603. http://dx.doi.org/10.1016/j.buildenv.2006.01.009

[5] Karjalainen, S. 2007. User problems with individual temperature control in offices, Building and Environment 42: 2880-2887. http://dx.doi.org/10.1016/j.buildenv.2006.10.031

[6] Pakanen, J.; Karjalainen, S. 2006. Estimating static heat flows in buildings for energy allocation systems, Energy and Buildings 38: $1044-1052$. http://dx.doi.org/10.1016/j.enbuild.2005.12.002

[7] Parsons, K. C. 2002. The effects of gender, acclimation state, the opportunity to adjust clothing and physical disability on requirements for thermal comfort, Energy and Buildings 34: 593-599. http://dx.doi.org/10.1016/S0378-7788(02)00009-9

[8] Frontczak, M.; Wargocki, P. 2011. Literature survey on how different factors influence human comfort in indoor environments, Building and Environment 46: 922-937. http://dx.doi.org/10.1016/j.buildenv.2010.10.021

[9] Tsilingris, P. T. 2004. On the thermal time constant of structural walls, Applied Thermal Engineering 24: 743-757. http://dx.doi.org/10.1016/j.applthermaleng.2003.10.015

[10] Strub, F.; Castaing-Lasvignottes, J.; Strub, M.; Pons, M.; Monchoux, F. 2005. Second law analysis of periodic heat conduction through a wall, International Journal of Thermal Sciences 44: 1154-1160. http://dx.doi.org/10.1016/j.ijthermalsci.2005.09.004

[11] Shalin, P. 1996. Modelling and simulation methods for modular continuous system in buildings. Doctoral Dissertation, KTH, Stockholm.

[12] Moinard, S.; Guyon, G. (Eds.). 1999. Empirical Validation of EDF ETNA and GENEC Test-Cell Models. Subtask A.3, A Report of IEA Task 22, Building Energy Analysis Tools, 1999, 68 p

[13] Achermann, M.; Zweifel, G. 2003. RADTEST_Radiant Heating and Cooling Test Cases. Subtask C, AReport of IEATask 22, Building Energy Analysis Tools, 2003, $83 \mathrm{p}$.

[14] Kalamees, T.; Kurnitski, J. 2006. Estonian test reference year for energy calculations, in Proceedings of the Estonian Academy of Sciences Engineering 12(1): 40-58. 